\title{
Marine Fish Breeding in Brazil - A Potential Activity in the Dormant Stage
}

\author{
Dacley Hertes Neu*, Claucia Aparecida Honorato and Vanessa Lewandowski \\ Federal University of Grande Dourados, Brazil
}

*Corresponding author: Dacley Hertes Neu, Federal University of Grande Dourados , UFGD, Rodovia Dourados , Itahum, Brazil.
Received Date: December 18, 2018

Published Date: January 08, 2019

\begin{abstract}
Marine fish farming in Brazil is a little practiced activity, and in this context, it does not follow the global growth behavior. A number of obstacles are evident, such as the lack of skilled labor, adapted equipment, burdensome time-consuming and on-going environmental licensing among regulators, and the lack of established technology packages for most potential species. On the other hand, several positive points can be listed, such as the climate conducive to the activity and the necessary inputs for the preparation of the rations. This activity can be considered strategic for the production of food of high biological value, but measures must be taken for companies to enter and remain in the activity on the Brazilian coast.
\end{abstract}

Keywords: Marine fish farming panorama, Challenges and potential of marine fish farming, Fish farming perspective of the Marine.

\section{Challenges and Perspectives of Brazilian Marine} Fish Farming

Fish farming is a growing agricultural activity worldwide and in Brazil, it is no different, however, there is a particularity in the use of environments. Here, marine fish farming is embryonic, that is, products originating from this activity are not even counted in the fishery production statistics. In a scenario of population growth, water becomes a great option for food production, and in this context marine fish farming can play a fundamental role in human nutrition .

Marine fish production is already consolidated in some countries in Asia and Europe with species such as milkfish (Chanos chanos), Atlantic cod (Atlantic cod), European sea bass (Dicentrarchus labrax), sole (Psetta maximum), among others (Lucas and Southgate). Despite the development of new farming technologies to active it, to increase the supply of marine animal protein [1], marine fish farming is still not globally representative, both in terms of production and economically.

According to statistical data of FAO [2,3], in the year 2016 were pre oduzidos 80 million tons of fish and this amount hoes 28,600 tons of product aquaculture of marine origin have been generated, corresponding to $35 \%$ being represented mainly by the cultivation of molluscs. Marine fish farming accounted for only $8 \%$ of world aquaculture production.

Brazilian fish farming mainly uses inland waters to produce fish, while the waters of the seas and oceans are practically obsolete in the sense of food production. Although Brazil has an enormous amount of water resources, it accounts for $12 \%$ of the world's freshwater reserves, which comprise more than 5 million hectares of water slides in natural and artificial reservoirs [4]; there are more than $8,400 \mathrm{~km}$ of coastal area, two hundred miles of territorial sea and Exclusive Economic Zone and 2.5 million hectares of estuarine areas [5] which sends the country to a prominent scenario, and in this sense, marine fish farming is strategic for the production of animal protein.

Some native fish species were listed as potentials for production [5], such as kingfish (Odontesthes argentinensis), sea bass (Centropomus parallelus), mullet (Mugil sp,.), sole (Paralichthys orbignyanus), b and ijupirá (Rachicentron Canada) and the ornamental seahorse (Hippocampus reidi). Cavalli RO, et al. [6] also point out that there are other species that have been systematically studied. However, the technological package is not established at national level for any of them. According to Cavali RO [7] despite the 
efforts in research and development, the creation of these species has no relevant commercial importance as it is incipient.

However, Cavalli RO [7], Cerqueira VR, et al. [8] and Souza Lima et al. [9] emphasize that the beijupirá has a potential role in the development of Brazilian marine fish farming, either because it is a native species that would facilitate environmental licensing, or because of its fast growth rate, easy management and known reproduction, among other factors such as the characteristic of meat that make it attractive and the cost of production that can be reduced if there is an increase in scale.

If on the one hand the creation of marine fish has good prospects [8], because the climate in the country is favorable to the practice of fish farming, there are foods that can be transformed into diets for the various species of fish and there is hand of abundant work , besides the several research institutes that can contribute in the different segments of the productive chain, there are still several points to be filled, and these make marine fish farming limiting and embryonic in national territory.

Meanwhile, po to be highlighted several pond tosses covering biological, economic and legal. For an activity to be representative on a large scale, it is necessary to master all the stages of the productive cycle of what one intends to cultivate. There are still several gaps in the biological factors of Brazilian marine fish that still need to be answered. However, Sampaio LA, et al. [10] point out that as the beijupirá is cultivated abroad, with technology already developed, the information already obtained can be used as a basis for its cultivation in Brazil, thus eliminating basic research steps.

For native species in general, there is still a lack of information and mastery of the processes of reproduction, production of young forms and fattening. Unlike freshwater fish, in which an established protocol for captive breeding has been established, marine fish respond differently to the methods used for breeding, with variations occurring both in species and in relation to the sexism [8]. With this, it is necessary to carry out specific studies for each species in order to define the best protocol of reproductive management, spending time and resources.

The larvae and the production of young forms shown as a major bottleneck activity. The marine fish larvae are small and fragile, erupting with yolk sac with smaller size when compared to freshwater fish larvae $[11,12]$. In the wild state, the copepods are the basis of the initial diet of these species, due to the ideal movement, nutrients in adequate quantity and quality, with high levels of highly unsaturated fatty acids [13]. However, as copepod cultivation is still an activity of low efficiency and cost el evade, rotifers and artemia are used as a food source and must first go through an enrichment process, which increases the costs of this phase of cultivation [14].

The provision of live food is required in the first feeding in the quantity and quality, since due to the high voracious larvae, the inadequate availability of food stimulates cannibalism and causes high mortality by starvation. In addition, because the larva has a small yolk sac, its energy reserves are rapidly consumed [15], further reinforcing the importance of live food, since it has better nutritional characteristics when compared to artificial diets.

However, for the viability of production, it is necessary to carry out the transition from live to inert diet. This point is crucial in the stage of aviculture and directly interferes in obtaining young forms. Sanches et al. [14] in a study with beijupirá, demonstrate that larvae survival is a fundamental factor for the development of the activity, since, currently, there is demand, but a low supply, resulting in a higher sale price of the young forms and influencing in the viability of the entire production chain.

Not least, the nutrition of these species needs to be determined for the various stages of development, whether in larval or fattening, fish need to be well nourished to express the best growth over a long period of time. Nevertheless, the food supplied must have a high coefficient of digestibility, providing greater protein deposition and less environmental pollution. Some marine fish have a higher trophic level, requiring a ration with higher protein and energy content . Currently, no specific commercial diets are found in the market for native Brazilian marine fish, regardless of the development phase Tesser and Samapaio [16]. D use to this gap, are generally employed feed to produce other species of carnivorous fish Tsuzuki and Berestinas [11] and unfortunately do not provide optimal conditions nutrient use, when considering species-specific diets.

Feedings for carnivorous fish generally contain higher amounts of flour and fish oil [3] in their constitution. In Latin America find much flour as fish oil is not necessarily a problem (Peru is the largest producer), except for the cost that is up to four times higher than soybean meal, however, the studies already switching to replace these foods from other sources such as oils and vegetable origin proteins [17] Lunger et al. [18] FAO [3]. or even migrate $\mathrm{n}$ to multitrophic aquaculture models Little et al. [19].

Nutrition can account for more than $50 \%$ of production costs and can reach up to $70 \%$ depending on the system and the intensification of production. As marine fish are nowadays mainly raised in tank-net systems with high stocking densities, costs will stay close to this higher mentioned. Therefore, reducing these numbers are crucial for good development, and in this point, Brazil is prominent because it produces large amounts of soy and maize, the main constituents of a feed.

The legal factors also exert a great influence on the viability of marine fish production, mainly through the Environmental Licensing. The authorization for the use of physical spaces of water bodies of Union domain for aquaculture purposes is given by decree number $4895 / 2003$. While this apparatus is an important and necessary point, it is a time-consuming mechanism Hilbig et al. [20], which also implies conflicts over the legal attributions of supervision and licensing, which, as a rule, passes through more than one regulatory/ regulatory body leading to times greater than one year to start activities. 
Another point that leads to the discouragement of marine fish farming is the lack of specialized manpower and equipment destined to this segment Cavalli and Hamilton [15]. Generally, it uses adjustments to the equipment and infrastructure of farmed tilapia or round fish common in Brazil, for marine activity, and many of these tailored products do not meet the requirement of the activity, either by size of the specimens to be worked either by materials that do not withstand intense stress. The production units (cages) installed in the sea are subject to the action of winds and waves and with that, their structures must be designed to support these forces Huang, et al. [1]. As the production units of freshwater fish have different characteristics, being smaller and less resistant, aiming at a property with an efficient production system, it is necessary to resort to imports of structures and equipment Domingues, et al. [21].

Currently, the few marine fish production sites in Brazil are located near the coast, in places sheltered by strong winds and currents, but following a trend already observed in more advanced countries in the activity, new offshore areas in off - shore can be considered Huang, et al. [1]. This behavior is observed due to conflicts of interest in possible areas of implantation of a marine fish farming unit with other activities, such as tourism and urban development on the coast Tidwell JH [22]. However, it is worth mentioning that in bringing the aquaculture property to the open sea, the care and expense in relation to the structures and equipment is increased, considering that they should be more resistant, in addition to the need for larger structures to support the management routines Tidwell JH [22].

Cavalli (2012) also emphasizes that activity sanity requires and will require trained personnel / laboratories and equipment to identify and diagnose in a timely manner the possible diseases or pathogens that can be established in animals. And this is a crucial point, because as animals are subject to the weather as well as remain confined to high densities, speed in decision making will ensure the success of production when something negative occurs.

But one factor is paramount, are aggregated taxes on products, and it is noteworthy not only aquaculture but the entire agricultural chain. Kubitza et al. [23]. report that due to the large tax burden in Brazil, there is an excessive burden on the price of inputs, labor, energy, equipment and services for the sector, which ends up limiting the country to compete with external products. This, consequently, causes in distrust of the investor who prefers not to put his business if there is financial risk. In addition, Domingues et al. [21]. the taxes involved in the importation of structures and equipment correspond to $20 \%$ of the costs of installation of the production unit.

\section{Final Considerations}

The Brazilian aquaculture growth forecast is $89 \%$ for the year 2030, reaching 1,097million tons FAO [3], but it is not possible to predict the impact of marine aquaculture on these values.

Considering that the aquaculture activity is food producing, and that it can satisfy the hunger of several people, even of whole families, and that these products are often the only source of protein used in the diet Hilbig et al. [24,25], special attention should be paid to aquaculture and marine fish farming.

In this sense, it is of the utmost importance that the government create conditions for companies to establish themselves in the coastal area, as it is an extremely favorable place and continues to be neglected by the authorities. There is no doubt that, in a short space of time, these environments will be pursued by companies in order to develop a commercially competitive product with a guarantee of environmental sustainability. For this to take place scientific research must be approached by closing the existing gaps, as well as the study of some tool that reduces the amount of taxes or create subsidies for the sector.

\section{Acknowledgment}

None.

\section{Conflict of Interest}

\section{No conflict of interest.}

\section{References}

1. Huang X, Guo G, Tao Q Hu Y, Liu H, et al. (2016) Numerical simulation of deformatins and forces of a floating fish necklace in waves. Aquacultural Engineering 74: 111-119.

2. FAO (Food and Agriculture Organization of the United Nations), Global Aquaculture Production 1950-201 6. Fish Stat.

3. FAO (Food and Agriculture Organization of the United Nations), The state of world fisheries and aquaculture 2018: Meeting the sustainable development goals. Rome.

4. Well GW, Marengoni NG, Gonçalves Júnior AC, Boscolo WR (2008) Status Trophic and bioaccumulation of total phosphorus in fish culture in net tanks in the aquaculture network of the Itaipu reservoir. ActaScientiarum Biological Sciences 30(30): 237-243.

5. Baldisserotto, Gomes BL (2013) Native species for fish farming in Brazil. Santa Maria: UFSM Publishing House, ( $2^{\text {nd }}$ edn) p.608.

6. Cavalli RO, Hamilton S, (2009) Marine fish farming in Brazil with emphasis on the production of beijupirá . Brazilian Journal of Animal Reproduction 6, p. 64-69.

7. Cavalli RO, (2012) With excellent environmental conditions, marine fish farming needs investments. Agricultural View 2: p. 18-23.

8. Cerqueira VR, Carvalho CVA, Sanches EG, Passini G, Baloi M, et al. (2017) Reproductive management and control of the reproduction of marine fish of the Brazilian coast. Magazine Brazilian Journal of Animal Reproduction 41(1): 94-102.

9. Souza Lima LNS, Hamilton S, Bezerra TRQ Cavalli RO (2018) Identification of areas with adequate temperature for the culture of the cobia in cages along the Brazilian Coast. Brazilian Journal of Agricultural Sciences 13(3): 1-5.

10. Sampaio LA, Tesser MB, Wasielesku W (2010) Advances in mariculture in the first decade of this century: fish and marine carcinoculture. Revista Brasileira de Zootecnia 39: p.102-111.

11. Lucas JS, Southgate PC (2012) Aquaculture: farming aquatic animal and plants. Oxford: Blackwell Publishing, USA, p643.

12. Moksness E, Kjorsvik E, Olsen Y (2004) Culture of cold-water marine fish. Oxford: Blackwell Publishing, USA, p 543.

13. Calado R, Olivotto I, Oliver MP, Holt GJ (2017) Marine ornamental species aquaculture. Chichester : John Wiley \& Sons, USA, p.736.

14. Sanches EG, Tosta GAM, Souza Filho JJ (2013) Economic viability of the production of young forms of bijupirá (Rachycentron canadum). Bulletin of the Institute of Fisheries 39(1): 15-26. 
15. Kohno H, Ordonio Aguillar R, Ohno A, Taki Y (1997) Why is grouper larval rearing difficult? In the approach from the development of the feeding apparatus in early stage larvae of the grouper, Epinephelus cooides .Ichthyological Research 44(3): 267-274.

16. Tesser MB, Sampaio LA, (2006) Creation of kingfish juveniles (Odontesthes argentinensis) at different feeding rates . Ciência Rural 36(4): 1278-1282.

17. Daniel N (2018) A review on replacing fish meal in aqua feeds using plant protein sources. International Journal of Fisheries and Aquatic Studies 6(2): 164-179.

18. Lunger AN, Craig SR, McLean C (2006) Replacement of fish meal in cobia (Rachycentron canadum) diets using an organically certified protein. Aquaculture 257(1-4): 393-399.

19. Little DC, Newton RW, Beveridge MCM (2016) Aquaculture: a rapidly growing and significant source of sustainable food? Status, transitions and potential. Proceedings of the Nutrition Society 75: 274-286.
20. Hilbig CC, Neu DH, Santos RC, Reis JGM, Costa Neto (2018) Production Engineering Applied to Agribusiness. São Paulo: Blucher, 312

21. Domingues EC, Hamilton S, Bezerra TRQ, Cavalli RO (2014) Economic viability of beijupirá creation in the open sea in Pernambuco. Bulletin of the Institute of Fisheries 40(2): 237-249.

22. Tidwell JH (2012) Aquaculture production systems. Iowa: John Wiley \& Sons, USA, p. 415.

23. Kubitza F, Campos JL, Ono EK, Istchuk PI (2012) Panorama of fish farming in Brazil: Regional characteristics of fish farming, production costs and sales prices, bottlenecks limiting crop expansion. Aquaculture Overview 14-23.

24. Hilbig CC, Neu DH, Santos RC, Reis JGM, Costa Neto (2018) Production Engineering Applied to Agribusiness. São Paulo: Blucher, 312.

25. Cavalli RO, Ferreira JF (2010) The future of marine fisheries and aquaculture in Brazil: Mariculture. Science and Culture. 62(3): 38-39. 